\title{
PENETAPAN KADAR AKRILAMIDA PADA KENTANG GORENG YANG BEREDAR DI RESTORAN CEPAT SAJI DI KOTA MANADO DENGAN MENGGUNAKAN SPEKTROFOTOMETRI UV-VIS
}

\author{
Leobernard Butue $^{1)}$, Fatimawali ${ }^{1)}$, Defny S. Wewengkang ${ }^{1)}$ \\ ${ }^{1)}$ Program Studi Farmasi FMIPA UNSRAT Manado, 95115
}

\begin{abstract}
Acrylamide has been classified as a cancer causing compound or potentially carcinogenic in humans. Acrylamide is produced from foods that contain high carbohydrates with temperatures over $120^{\circ} \mathrm{C}$ in processing. One of foods that are popular and potentially produce acrylamide compounds was fried potato. This study aims to determine the levels of acrylamide contained in french fries using UV-Vis Spectrophotometry method. Samples were obtained from 3 fast food restaurants in the City of Manado. In this study the analysis of acrylamide compounds from 3 samples were carried out at $267 \mathrm{~nm}$ wavelength using an aquadest blank with 2 repetitions. The estimated result of three samples are $K$ samples of $0.69 \mu \mathrm{g} / \mathrm{g}, M$ of $0.58 \mu \mathrm{g} / \mathrm{g}$, and $T$ samples of $0.67 \mu \mathrm{g} / \mathrm{g}$. The three samples did not contain acrylamide because the levels obtained were still below the detection limit (LOD) of 1.54 $\mu g / g$.
\end{abstract}

Keywords: Acrylamide, French Fries, UV-Vis Spectrophotometry, Fast Food Restaurants in Manado.

\begin{abstract}
ABSTRAK
Akrilamida telah diklasifikasikan sebagai senyawa yang menyebabkan kanker atau berpotensi sebagai karsinogenik pada manusia. Akrilamida dihasilkan dari makanan yang mengandung karbohidrat tinggi dengan suhu lebih dari $120^{\circ} \mathrm{C}$ pada pengolahannya. Makanan yang banyak digemari serta berpotensi menghasilkan senyawa akrilamida salah satunya adalah kentang goreng. Penelitian ini bertujuan untuk menetapkan kadar akrilamida yang terkandung dalam kentang goreng dengan menggunakan metode Spektrofotometri UV-Vis. Sampel diperoleh dari 3 restoran cepat saji di Kota Manado. Pada penelitian ini analisis senyawa akrilamida dari 3 sampel dilakukan pada panjang gelombang $267 \mathrm{~nm}$ menggunakan blanko aquadest dengan 2 kali pengulangan. Hasil perhitungan dari ketiga sampel adalah sampel $\mathrm{K}$ sebesar $0,69 \mu \mathrm{g} / \mathrm{g}$, M sebesar 0,58 $\mu \mathrm{g} / \mathrm{g}$, dan sampel $\mathrm{T}$ sebesar $0,67 \mu \mathrm{g} / \mathrm{g}$. Ketiga sampel tidak mengandung akrilamida karena kadar yang didapat masih berada di bawah batas deteksi (LOD) yang didapat yaitu $1,54 \mu \mathrm{g} / \mathrm{g}$.
\end{abstract}

Kata Kunci:Akrilamida, Kentang Goreng, Spektrofotometri UV-Vis, Restoran cepat saji di Manado 


\section{PENDAHULUAN}

Kentang goreng adalah salah satu makanan olahan dari kentang yang banyak di minati semua kalangan terutama anakanak dan remaja. Kentang goreng banyak tersedia direstoran-restoran cepat saji, kedai kopi dan kafe. Makanan ini banyak minati karena memiliki rasa yang gurih dan harga yang terjangkau. Makanan yang goreng seperti kentang juga dapat menjadi penyebab berbagai macam penyakit seperti, meningkatnya kadar kolesterol, stroke, penyakit jantung koroner, bahkan dapat menjadi pemicu kanker. Salah satu senyawa pemicu kanker yang di temukan pada kentang goreng adalah akrilamida (Dewi, 2010).

Akrilamida (sinonim : 2-propenamida, etilen karboksiamida, akrilik amida, asam propeonik amida, vinil amida) ialah senyawa kimia yang biasa di gunakan manusia dalam kehidupan sehari-hari untuk memproduksi plastik. Zat ini juga biasanya di gunakan dalam pengolahan dan penjernihan air (BPOM, 2004). Akrilamida merupakan senyawa toksik dalam bentuk monomer, sedangkan poliakrilamida yang merupakan polimernya tidak lagi bersifat toksik (Sulistyawati, 2010). Akrilamida terdapat dalam makanan bukan karena cemaran dari luar, tetapi di sebabkan oleh pemanasan asam amino dan gula yang terdapat dalam makanan pada suhu tinggi. Asparagin yang merupakan asam amino utama dalam kentang dan memiliki struktur mirip dengan akrilamida di duga sebagai senyawa yang paling berperan dalam pembentukan akrilamida (Harahap, 2006).

$$
\text { World Health Organization (WHO) }
$$

pada tahun 2002, memutuskan bahwa akrilamida bersifat karsinogenik (toksik dalam materi genetik dalam sel). Akrilamida dapat di absorpsi pada saluran gastrointestinal, di distribusikan secara luas oleh cairan tubuh dan dapat menembus membran plasenta. Senyawa ini juga neurotoksik (toksik terhadap sel saraf) dan secara oral dapat meningkatkan resiko kanker skrotal, tiroid, tumor adrenal pada tikus jantan serta meningkatkan resiko kanker mammae, tiroid dan tumor uterin pada tikus betina. Environmental Protection Agency (EPA) pada tahun 1992, mengklasifikasikan akrilamida sebagai senyawa yang kemungkinan bersifat karsinogenik terhadap manusia. World Healt Organization (WHO) menyatakan bahwa pada populasi umum, rata-rata asupan akrilamida melalui makanan berada pada rentang 0,3-0.8 $\mu \mathrm{g} / \mathrm{kg} \quad \mathrm{BB} / \mathrm{hari}$ (FDA, 2004).

Penelitian tentang akrilamida telah di lakukan oleh peneliti-peneliti sebelumnya, di antaranya oleh Hermanto dan Adawiyah (2010) tentang akrilamida yang terdapat dalam sediaan roti kering yaitu 0,0541 \pm 0,$0270 ; 0,0850 \pm 0,062 ;$ dan 0,3445 \pm $0,2539 \mu \mathrm{g} / \mathrm{g}$. Selanjutnya penelitian di lakukan oleh Tandi (2012) kadar akrilamida dalam pisang goreng yang beredar di Kota Manado sebesar 39,65-1789,52 $\mu \mathrm{g} / \mathrm{kg}$.

Berdasarkan uraian di atas dan akhirakhir ini restoran cepat saji di Manado semakin meningkat maka penelitian ini di lakukan untuk mengetahui kadar akrilamida yang terkandung pada kentang goreng yang beredar direstoran-restoran cepat saji Kota Manado dengan menggunakan metode Spektrofotometri UV-Vis. Sampel kentang goreng di pilih karena menjadi salah satu makanan yang banyak di gemari semua kalangan serta berpotensi menghasilkan senyawa karsinogenik yaitu akrilamida.

\section{METODOLOGI PENILITIAN}

\section{Waktu dan Tempat Penelitian}

Penelitian ini di lakukan pada bulan Februari - April 2018 dilaboratorium 
Analisis Farmasi Fakultas Matematika dan Ilmu Pengetahuan Alam Universitas Samratulangi Manado.

Alat

Seperangkat alat Spektrofotometri UV - Vis (Shimadzu 00780), alat-alat gelas, mortar, mikro pipet (Ecopippete), vortex (Mixer Hwashin) dan timbangan analitik (ADAM).

\section{Bahan}

Bahan yang di gunakan dalam penelitian antara lain diklormetan, aquadest, akrilamida (p.a), kertas saring dan kentang goreng sebagai sampel yang di ambil dari tiga restoran cepat saji di Kota Manado.

\section{Pembuatan Larutan Standar}

Timbang sebanyak 0.1 gram akrilamida, kemudian di masukan ke dalam labu ukur $100 \mathrm{~mL}$. Kemudian di encerkan menjadi 100 ppm dengan aquadest sampai tanda batas. Selanjutnya, di buat larutan standar akrlamida dengan konsentrasi 2,5;5 ; 7,5; $10 ; 12,5$ dan 15 ppm.

\section{Penentuan Panjang Gelombang Maksimum Akrilamida}

Larutan standar akrilamida dengan konsentrasi $15 \mathrm{ppm}$ di buat, di ukur serapannya pada panjang gelombang 200$400 \mathrm{~nm}$ secara Spektrofotometri UV-Vis dan di tentukan panjang gelombang maksimum akrilamida.

\section{Pembuatan Kurva Standar}

Di ambil larutan standar Akrilamida dengan masing-masing konsentrasi, lalu di amati absorbansinya pada panjang gelombang $267 \quad \mathrm{~nm}$ menggunakan Spektrofotometri UV - Vis dengan blanko aquadest. Kemudian dari data yang di peroleh di buat kurva hubungan antara konsentrasi (C) versus absorbansi (A) sehingga di peroleh kurva standar berupa garis lurus.

\section{Batas Deteksi (LOD) dan Batas Kuantitasi (LOQ)}

Batas deteksi dan batas kuantitasi dihitung secara statistik melalui garis regresi linear dari kurva kalibrasi.

a. Batas deteksi (LOD)

$$
\begin{array}{ll}
\text { b. } & \text { BOD }=\frac{3 . S y / x}{\mathrm{Sl}} \\
& \mathrm{LOQ}=\frac{10 . \mathrm{Sy} / \mathrm{x}}{\mathrm{Sl}}
\end{array}
$$

\section{Pembuatan Larutan Sampel}

Sampel yang telah di pilih di haluskan dengan mortar kemudian timbang masingmasing sebanyak 2 gram selanjutnya di larutkan dengan diklormetan $25 \mathrm{~mL}$ dan di vortex selama 30 menit. Setelah larutan menjadi homogen, larutan selanjutnya di saring dengan kertas saring sebanyak 2 kali dan di tambahkan dengan aquadest sebanyak $10 \mathrm{~mL}$. Selanjutnya, larutan di uapkan pada suhu $70^{\circ} \mathrm{C}$ sampai diklormetan menguap seluruhnya (Harahap, 2005).

\section{Analisis Kadar Akrilamida}

Ambil masing-masing larutan sampel sebanyak $1 \mathrm{~mL}$ ke dalam labu ukur $25 \mathrm{~mL}$ kemudian di larutkan dengan aquadest sampai tanda batas. Masing-masing sampel di baca dengan Spektrofotometri UV-Vis sebanyak 2 kali pengulangan dengan blanko aquadest pada panjang gelombang $267 \mathrm{~nm}$. Kadar akrilamida dalam sampel di hitung dengan menggunakan persamaan kurva kalibrasi.

\section{HASIL DAN PEMBAHASAN}

\section{Sampel Kentang Goreng}

Tiga sampel yang telah di analisis di ambil dari tiga restoran cepat saji yang berbeda dikota Manado dan merupakan 
restoran yang ramai di kunjungi oleh masyarakat Kota Manado. Tiga sampel di beri kode label berturut sampel $\mathrm{K}, \mathrm{M}$ dan $\mathrm{T}$.

\section{Panjang Gelombang Maksimum}

Panjang gelombang yang di gunakan untuk analisis akrilamida adalah $267 \mathrm{~nm}$. Pengukuran panjang gelombang menggunakan Spektrofotometri UV-Vis dengan konsentrasi akrilamida sebesar 15 ppm dan di ukur pada rentang panjang gelombang 200-400 nm menggunakan pelarut aquadest.

\section{Kurva Kalibrasi Larutan Baku}

Persamaan regresi

$\mathrm{Y}=0,0448 \mathrm{x}+0,0473$.

Koefisien korelasi (r) : 0,99.

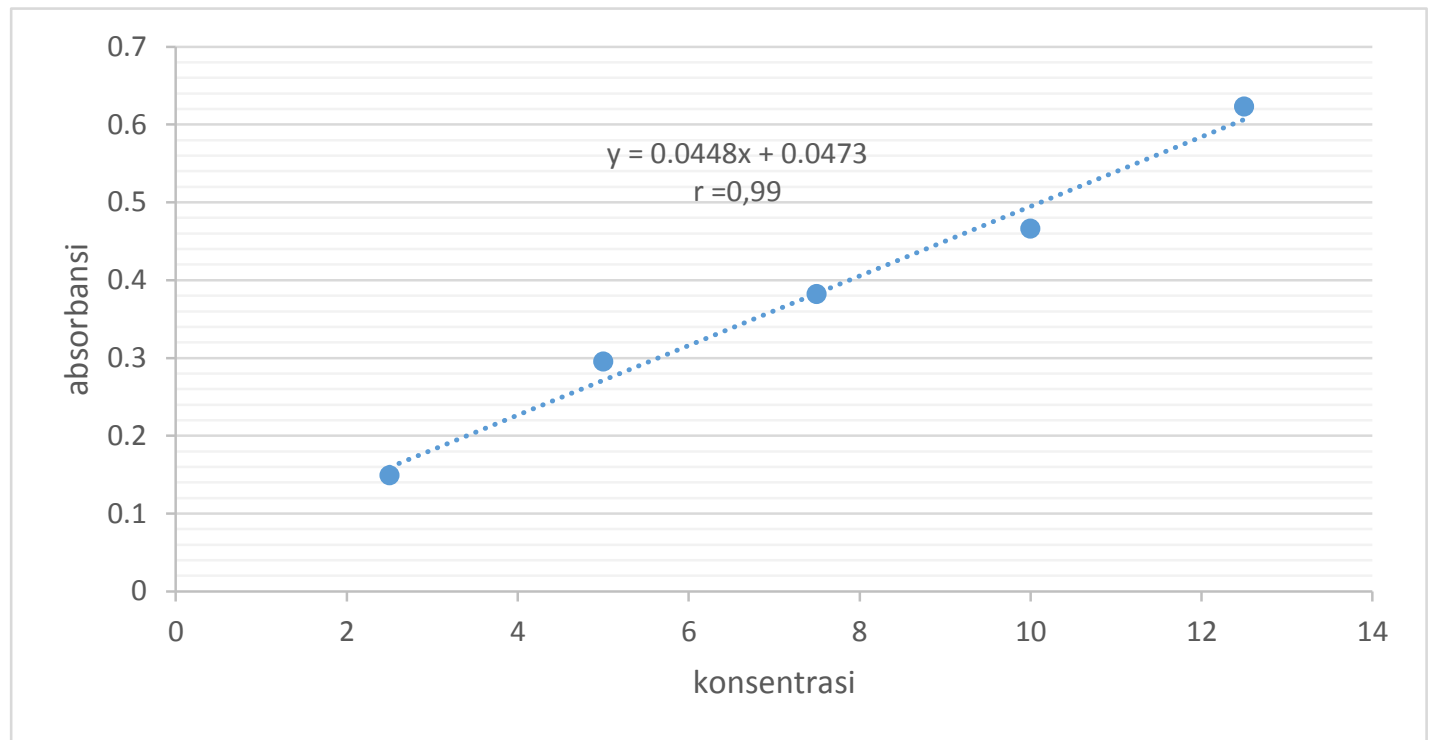

Gambar 1. Kurva kalibrasi regresi linear akrilamida baku

Batas deteksi (LOD) dan Batas kuantitasi (LOQ).

Batas deteksi (LOD)

$$
\begin{aligned}
& \mathrm{LOD}=\frac{3 . \mathrm{Sy} / \mathrm{x}}{\mathrm{Sl}} \\
& \mathrm{LOD}=\frac{3 \times 0,0243204303683}{0,0473}=1,54
\end{aligned}
$$

Batas kuantitasi (LOQ)

$$
\begin{aligned}
& \mathrm{LOQ}=\frac{10 . \mathrm{Sy} / \mathrm{x}}{\mathrm{Sl}} \\
& \mathrm{LOQ}=\frac{10 \times 0,0243204303683}{0,0473}=5,14
\end{aligned}
$$

\section{Kadar Akrilamida dalam Sampel}

Kadar akrilamida dalam sampel di hitung dengan persamaan kurva kalibrasi.

1. Kadar rata-rata akrilamida dalam sampel $\mathrm{K}$ adalah $0,69 \mu \mathrm{g} / \mathrm{g}$.

2. Kadar rata-rata akrilamida dalam sampel $\mathrm{M}$ adalah $0,58 \mu \mathrm{g} / \mathrm{g}$.
3. Kadar rata-rata akrilamida dalam sampel T adalah $0,67 \mu \mathrm{g} / \mathrm{g}$.

Seperti diketahui akrilamida secara nyata di temukan dalam makanan tertentu yang dalam proses dan pembuatannya (di goreng, di panggang dan di bakar) menggunakan suhu lebih dari $120^{\circ} \mathrm{C}$. Kadar akrilamida akan meningkat dengan meningkatnya suhu pemanasan dan bertambahnya waktu.

Penelitian ini bertujuan untuk menentukan kadar akrilamida yang terdapat dalam kentang goreng dengan menggunakan metode Spektrofotometri UV-Vis. Pada penelitian sebelumnya telah di lakukan analisis akrilamida dalam makanan dan berhasil mendeteksi sejumlah akrilamida di dalamnya. Oleh karena itu, penelitian 
tersebut di lanjutkan dengan menganalisis akrilamida menggunakan Spektrofotometri UV-Vis pada kentang goreng agar hasilnya kemudian dapat di gunakan sebagai informasi kepada masyarakat guna menekan efek karsinogenik yang mungkin di timbulkan. Metode Spektrofotometri UVVis di pilih karena cara kerjanya lebih sederhana, waktu analisisnya cepat dan biaya yang relatif murah.

Penelitian di mulai dengan menentukan panjang gelombang untuk analisis akrilamida, di lihat pada panjang gelombang berapa akrilamida memberi serapan menggunakan Spektrofotometri UV-Vis. Akrilamida dapat di deteksi dengan Spektrofotometri UV-Vis karena mempunyai gugus kromofor dan auksokrom. Panjang gelombang akrilamida yang di peroleh adalah $267 \mathrm{~nm}$, dengan konsentrasi larutan baku 15 ppm. Selanjutnya pada panjang gelombang $267 \mathrm{di}$ gunakan untuk menganalisis kadar akrilamida dalam kentang goreng. Sebelum sampel di analisis, sampel terlebih dahulu di ekstraksi yang bertujuan untuk menarik senyawa akrilamida dari ke tiga sampel kentang goreng. Sampel yang telah di pilih dan di haluskan dengan mortar kemudian timbang masing-masing sebanyak 2 gram selanjutnya di larutkan dengan diklormetan $25 \mathrm{ml}$ dan di vortex selama 30 menit. Setelah larutan menjadi homogen, larutan selanjutnya di saring dengan kertas saring sebanyak 2 kali dan di tambahkan dengan aquadest sebanyak $10 \mathrm{ml}$. Selanjutnya, larutan di panaskan pada suhu $70^{\circ} \mathrm{C}$ sampai diklormetan menguap (Harahap, 2005).

Penggunaan diklormetan dalam proses ekstraksi karena di ketahui bahwa diklormetan dapat menarik senyawa akrilamida dari sampel kentang goreng. Akrilamida sebenarnya memiliki kelarutan yang tinggi dalam air, namun dalam ekstraksi tidak langsung menggunakan air untuk menarik senyawa akrilamida dari sampel kentang goreng di karenakan banyaknya senyawa polar yang mungkin ikut terekstraksi bersama akrilamida sehingga akan mengganggu analisis. Selanjutnya, kelarutan akrilamida yang tinggi dalam air di manfaatkan untuk menarik akrilamida dari diklormetan tanpa terbawanya senyawa organik yang tidak larut dalam pelarut polar. Adanya kemungkinan bahwa tidak seluruh akrilamida tertarik ke dalam fase air, maka fase diklormetan akan di uapkan sehingga akrilamida yang tertinggal akan larut ke dalam fase air. Penguapan di lakukan pada suhu $70^{\circ} \mathrm{C}$, di bawah titik didih air dan di atas titik didih diklormetan.

Analisis senyawa akrilamida masingmasing sampel di lakukan dengan Spektrofotometri UV-Vis pada panjang gelombang $267 \mathrm{~nm}$. Perhitungan pada hasil analisis sampel kentang goreng dilakukan dengan menggunakan persamaan regresi linear yaitu $\mathrm{Y}=\mathrm{ax}+\mathrm{b}$. Hasil yang didapat dari ke tiga sampel dari tinggi ke rendah adalah sampel $\mathrm{K}$ sebesar $0,69 \mu \mathrm{g} / \mathrm{g}, \mathrm{T}$ sebesar 0,67 $\mu \mathrm{g} / \mathrm{g}$, dan M sebesar $0,58 \mu \mathrm{g} / \mathrm{g}$. Berdasarkan hasil perhitungan batas deteksi (LOD) dan batas kuantitasi (LOQ) yang didapat yaitu 1,54 untuk LOD dan 5,14 untuk LOQ, menunjukan bahwa semua sampel yang dianalisis tidak terdeteksi senyawa akrilamida karena kadar yang didapat dari sampel $\mathrm{K}, \mathrm{M}$, dan $\mathrm{T}$ tidak melebihi dari batas deteksi yang didapat.

Akrilamida tidak terbentuk dalam makanan yang pengolahannya di bawah $120^{\circ} \mathrm{C}$. Mekanisme terbentuknya belum dapat di ketahui dengan pasti, diperkirakan meliputi reaksi dari berbagai macam kandungan dalam makanan seperti karbohidrat, lemak, protein dan asam amino serta berbagai macam komponen lainnya dalam jumlah yang kecil. Akrilamida di anggap reaksi samping dari reaksi Maillard, 
yakni reaksi yang berlangsung antara asam amino dengan gula pereduksi (glukosa, fruktosa, ribose dan lain-lain). Asparagin merupakan asam amino yang terkandung dalam makanan seperti kentang yang merupakan komponen penting dalam
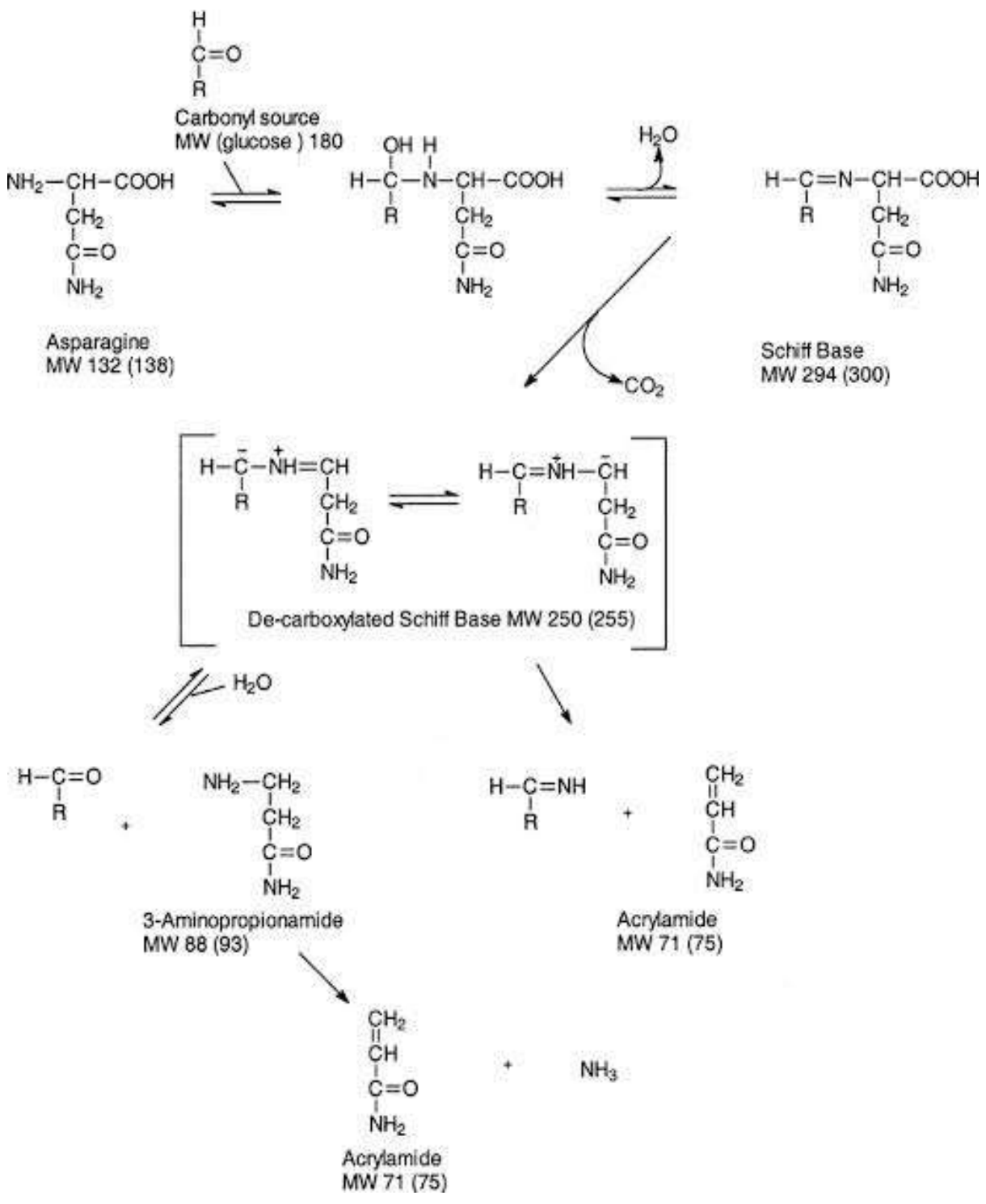

Gambar 2. Reaksi pembentukan akrilamida melalui reaksi Maillard

\section{KESIMPULAN}

Berdasarkan penelitian yang telah di lakukan ditarik kesimpulan bahwa ketiga sampel yang di peroleh dari 3 restoran cepat saji dikota Manado ketiganya tidak terdeteksi mengandung senyawa akrilamida. produksi akrilamida melalui mekanisme degradasi Strecker reaksi Maillard. Selain asparagin, asam amino glutamin juga dapat mengakibatkan pembentukan akrilamida meskipun kekuatannya jauh lebih rendah. 
yang didapat masih berada di bawah batas deteksi (LOD) yang didapat yaitu $1,54 \mu \mathrm{g} / \mathrm{g}$.

\section{SARAN}

Penelitian selanjutnya diharapkan dapat mengidentifikasi senyawa akrilamida pada olahan kentang lainnya.

\section{DAFTAR PUSTAKA}

BPOM. 2004. Akrilamida dalam Makanan: Dapatkah Menyebabkan Kanker. Info POM. Vol. 5. No. 6: Hal 6.

Dewi, P. S. 2010. Penetapan Akrilamida dalam Kentang Goreng pada Restoran Cepat Saji di Kota Medan Secara Kromatografi Cair Kinerja Tinggi [skripsi]. Fakultas Farmasi USU, Medan.

Harahap, Y. 2006. Pembentukan Akrilamida dalam Makanan dan Analisisnya. Majalah Ilmu Kefarmasian. Jurnal Ilmiah Sains Vol. III. No. 3. Hal: 107 $-116$.

Hermanto, S., R, Adawiyah. 2010. Analisis Akrilamida dalam Sediaan Roti
Kering Secara KCKT [skripsi]. Fakultas Sains dan Teknologi UIN, Jakarta.

Sulistyawati, E. 2010. Polimerisasi Akrilamida dengan Metode Mixed Solvent Precipitation Menggunakan Inisiator Kalium Persulfat. Yokyakarta.

Tandi, D. 2012. Analisis Kandungan Akrilamida dalam Pisang Goreng yang Beredar Di Kota Manado Menggunakan Kromatografi Cair Kinerja Tinggi [skripsi]. FMIPA UNSRAT, Manado.

U.S. Food and Drug Administration (FDA, 2004) Acrylamide Questions and Answera. Center for Food Safety and Applied Nutrition 2003.

WHO, 2002. Health Implication of Acrylamide in Food: Report of a Joint FAO/WHO Consultation. Geneve, Swiss: World Health Organization (WHO). 